\title{
Od tréninkového centra $k$ převládajícímu paradigmatu poválečné sociologické metodologie. Cesta kolumbijské školy od porážky k vítězství
}

\author{
HYNEK JEŘÁBEK**
}

\author{
From Advanced Training Center to the Predominant Paradigm of Post-war Sociological \\ Methodology. Road of the Columbia School from the Defeat to the Victory
}

\begin{abstract}
In the early 1950s BASR at Columbia University applied to become a training centre in sociological research for doctoral students. In 1950 Paul Lazarsfeld and R. K. Merton submitted a Memorandum to Columbia University that contained a well-argued proposal for BASR to be transformed into an Advanced Training Centre in Social Research. However, the Ford Foundation, which was funding the entire event, selected a rival project. In the western United States, in Palo Alto, California, it founded a new institution called the Center for Advanced Studies, devoting 3.5 million USD to its construction. Following this decision Paul Lazarsfeld and Robert Merton prepared and presented a project for the management of Columbia University called the "Planning Project for Advanced Training" (PPAT), for which the university managed to obtain 120,000 USD from the Rockefeller and Ford foundations. The project aimed to focus mainly on specific publications that could then be used to train doctoral students in the work of research. Lazarsfeld and his methodological school used almost all of the project's resources to publish several key methodological monographs through the renowned Free Press. Lazarsfeld, with the help of R. K. Merton and the university, managed by means of these focused publishing activities that supported examples of applied work by BASR and Columbia University to advance the Columbia school of sociology's methodological model as the leading paradigm of sociological research and doctoral education during the first two post-war decades in the USA and Western Europe.
\end{abstract}

Keywords: Advance Training Center; Paul Lazarsfeld; social research; Columbia school

DOI: $10.14712 / 23363525.2019 .19$

\section{Úvod}

Předložená stat’ si klade za úkol zodpovědět výzkumnou otázku: Čím přispěli Paul F. Lazarsfeld a Robert K. Merton k prosazení a přijetí modelu empirického sociologického výzkumu Kolumbijské univerzity jako převládajícího paradigmatu poválečné sociologie? Budeme sledovat plány, aktivity a výsledky snažení této sociologické školy v letech po 2. světové válce a budeme v nich hledat klíč k zodpovězení položené otázky.

V popisu stavu poválečné, zejména americké, sociologie se poměrně shodují autoři mnoha směrů i metodologických zaměření. Některé prameny uvádějí „hegemonii“ nebo

\footnotetext{
Tento článek byl podpořen Grantovou agenturou České republiky Grant č. 18-13807S Lazarsfeldova metodologie a její využití v politické sociologii a komunikačních studiích v letech (1950-1976) a řešen také v rámci programu Progres Q15 - část FSV UK.

** Prof. PhDr. Hynek Jeřábek, CSc., Univerzita Karlova, Fakulta sociálních věd, Institut sociologických studií, U Křřže 8, 15800 Praha 5 - Jinonice. E-mail: hynek.jerabek@gmail.com
} 
převahu paradigmatické orientace či sociologické praxe $\mathrm{v}$ padesátých a šedesátých letech dvacátého století zaměřením sociologického výzkumu na „survey research“ nebo „kvantitativní sociologii“, tedy na reprezentativní empirické sociologické výzkumy, př́padně na pokusy jejich výsledky dílčím způsobem zobecňovat.

Podrobnějšímu rozboru se věnovala velmi informativní publikace Jean M. Conversové [Converse 1987]. I když si nekladla za cíl prokázat, že v USA se model „survey“ stával v poválečných letech postupně dominantním paradigmatem, její podrobný popis vývoje situace v letech 1946 až 1960 je velmi cenným svědectvím o tomto vývoji. Popisuje tři nejvýznamnějši výzkumné instituce, které spojovaly v poválečných Spojených státech empirický sociální výzkum a akademický svět sociologie. Vedle nich existovaly ještě komerční výzkumné agentury. Ty se však soustředovaly na výzkum trhu a výzkum veřejného mínění. Conversová zdůraznila, $\mathrm{v}$ čem byly silné stránky vưdčí instituce z této trojice - Kolumbijské sociologické školy a jejího výzkumného ústavu The Bureau of Applied Social Research (BASR) [Converse 1987: 267-304]. Upozornila na to, že Chicagské National Opinion Research Center (NORC) mělo výhodu ve sběru dat reprezentujících celé Spojené státy [Converse 1987: 305-339]. Třetí - Michiganské výzkumné centrum: The Survey Research Center, později Institute for Social Research, využívalo mezioborové spolupráce sociologů s psychology, politology a ekonomy [Converse 1987: 340-378]. Tyto tři výzkumné ústavy představovaly hlavní centra empirického sociálního výzkumu a zasloužily se o poválečné dominantní postavení výzkumu typu survey ve Spojených státech [Converse 1987: 239]. Přitom Kolumbijská sociologická škola měla ústřední postavení mezi nimi [Converse 1987: 267].

Jean Conversová zmiňuje také Lazarsfeldovy organizační a metodologické zásluhy o Kolumbijskou školu, význam BASR jako tréninkového centra a jmenuje Lazarsfelda a jeho spolupracovníky jako tvůrce významných tréninkových publikací pro výuku sociálnímu výzkumu [Converse 1987: 281-282]. Odlišný př́istup zvolila Jennifer Platt. Ta analyzovala a hodnotila vývoj jednotlivých sociologických výzkumných metod od jejich počátku až do roku 1960 a potvrdila rostoucí význam „survey“ v poválečném období [Platt 1996].

V české sociologii otázky vývoje sociologické metodologie včetně střetávání a střídání jednotlivých paradigmat jako první podrobněji zmínil Miloslav Petrusek [1993]. Ten zhodnotil také dílo R. K. Mertona v rámci Kolumbijské sociologické školy [Petrusek 2000]. Vývojem sociologie v USA se zabýval Jan Balon [2011]. Česká a československá sociologie $\mathrm{v}$ kontextu světového vývoje jsou také předmětem zájmu nedávné publikace Jana Balona a Marka Skovajsy [Skovajsa - Balon 2017].

Co se vlastně stalo za války a poté ve čtyřicátých a padesátých letech dvacátého století, že $\mathrm{v}$ poválečné sociologii v USA převládala orientace na kvantitativně zaměřené výzkumy a značná část financovaných projektů se ř́dila podle paradigmatu kolumbijské školy sociálního výzkumu? Z hlediska dějin empirického sociálního výzkumu patří mezi pozoruhodné publikace monografie Christiana Flecka. Ten ve své rozsáhlé práci věnované vzniku empirického sociálního výzkumu, sociologickým emigrantům z Evropy a roli filantropických nadací podrobně rozebral období před 2. světovou válkou i dobu 2. světové války, avšak posouzení poválečného období se již př́liš nevěnoval [Fleck 2011]. Poukázal na tvưrčí úlohu metodologa P. F. Lazarsfelda a jeho projektů spojených s Kolumbijskou univerzitou, zejména v prvním období let 1939-1944. Hledal vysvětlení vývojových linií sociologie za války v širších historických souvislostech a prokázal významnou úlohu hlavních 
filantropických nadací v těchto procesech. Přestože naše téma nepatřilo $\mathrm{k}$ jeho hlavním problémům, zmínil se o prudkém rozvoji empirického sociologického výzkumu. Napsal: „Ve třech desetiletích mezi polovinou dvacátých let a polovinou padesátých let došlo k dramatickému nárůstu empirického sociálního výzkumu“ [Fleck 2011: 325].

Vysvětlit proměnu paradigmatické orientace sociologie srovnáním jejího stavu před 2. světovou válkou a v dekádě či dvou dekádách po ní se snažila skupina autorů zabývající se převážně sociologickou teorií a epistemologií. Myšlenky těchto autorů [Turner - Turner 1990; Steinmetz 2007; Calhoun - VanAntwerpen 2007] se pokusím shrnout v následujícím přehledu. Nejsoustavněǰím zpracováním tohoto tématu je monografie Stephena P. Turnera a Jonathana $\mathrm{H}$. Turnera Neuskutečnitelná věda. Institucionální analýza americké sociologie [Turner - Turner 1990]. Když S. P. Turner a J. H. Turner nejprve věnovali pozornost vývoji americké sociologie od jejích počátků před rokem 1900 až do konce třicátých let dvacátého století, položili si v souvislosti s novým obdobím, které se naplno projevilo po druhé světové válce, dosti nečekanou otázku: „Jak se to mohlo stát [...], že 50 let poté, co byly v sociologii uděleny první doktoráty, mohli jít vzhůru do ústředních pozic v sociologii ,amatéři'?" Autoři monografie si v této souvislosti uvědomují „křehkost teoretických a metodologických tradic v sociologii“" [Turner - Turner 1990: 88]. Podle hodnocených souvislostí evidentně šlo o významné pozice autorů, kteří nevystudovali sociologickou teorii na některé z elitních vysokých škol ve Spojených státech, a přitom byli nadmíru úspěšní v získávání financí pro své sociologické výzkumy. Dikce této kapitoly se soustř̌edila na charakteristickou proměnu sociologie $\mathrm{v}$,empirickou vědu“, alespoň $\mathrm{z}$ hlediska rozvoje a finanční podpory disciplíny. Skeptické hodnocení empirického výzkumu se do značné míry týkalo kontrastu se situací teorie a malé podpory, které se sociologické teorii v poválečném období dostávalo. Podporu získával a rozvíjel se především empirický sociální výzkum typu „survey“.

Celou kapitolu 3 věnovali Stephen a Jonathan Turnerovi dvěma poválečným desetiletím, tedy v zásadě období od roku 1945 do roku 1965 [Turner - Turner 1990: 85-132]. Toto období charakterizovali změněnou úlohou nadací, jejich proměněnými prioritami [Turner Turner 1990: 89]. Podle těchto autorů nadace změnily „pravidla akademické hierarchie“. Jako př́ílady sponzorovaného výzkumu, který byl pozitivně přijímán nadacemi, uváděli Lazarsfeldovy výzkumné projekty. Podle Turnera a Turnera „Lazarsfeld vytvořil BASR ${ }^{1}$ tak, aby bylo připraveno provádět takové výzkumné projekty typu survey, pro něž by byl schopen získat podporu nadací [Turner - Turner 1990: 101]. „Pro zadavatele výzkumu (sponzora) Lazarsfeld připravil výzkumnou zprávu, zatímco pro akademickou obec publikoval monografie, typicky ve spoluautorství se zaměstnanci BASR. [...] Navíc jeho studenti psali pod jeho vedením disertační práce a využívali $k$ analýze takto získaná data" [Turner - Turner 1990: 101]. Později, když se situace změnila, také Lazarsfeldovo BASR začalo více využívat prostředky federálních vládních agentur. Turner a Turner však také charakterizovali toto poválečné období proměn snahou o př́ípravu profesionálně připravených sociologů schopných provádět empirický výzkum typu „survey“ [Turner - Turner 1990: 107-108]. Uvedli, že Výzkumná rada pro sociální vědy (SSRC) chtěla „připravit tréninkové

BASR je zkratkou již čtvrtého, neslavnějš́ího výzkumného ústavu, který Paul Lazarsfeld založil, tento při Kolumbijské univerzitě v New Yorku ve čtyřicátých letech 20. století. Celý název zněl The Bureau of Applied Social Research, tedy Ústav aplikovaného sociálního výzkumu. 
materiály v metodologii [...] a nastolit podmínky pro pokročilý trénink v kvantitativních metodách" [Turner - Turner 1990: 108].

Dalším $\mathrm{z}$ autorů, kteří diskutovali situaci po druhé světové válce v americké sociologii, byl George Steinmetz, jeden z autorů rozsáhlé kolektivní monografie Sociology in America. A History [Calhoun (ed.) 2007]. V kapitole 9 nazvané Americká sociologie pred a po 2. světové válce: (Přechodné) založení oboru poukázal na hlavní proměnu americké sociologie po 2. světové válce slovy: „Posun od relativní rovnosti mezi nepozitivistickou a pozitivistickou orientací z hlediska vědecké prestiže k podmínkám, za nichž pozitivismus, jak je zde chápán, byl zjevně hlavní" [Steinmetz 2007: 315-316]. Metodologický pozitivismus Steinmetz vymezil třemi podstatnými charakteristikami: epistemologickým závazkem odhalovat zákony, orientací na empirii a scientismem. Podle něj „po roce 1945[...] se stal metodologický pozitivismus univerzálně uznávaným všemi sociology bez ohledu na to, zda jej sami přijali anebo se mu jen přizpůsobili“ [Steinmetz 2007: 320]. Přitom podle něj „Kolumbia (University) hrála ústřední úlohu v pozitivistickém utváření oboru jak před rokem 1930 tak i po roce 1945“ [Steinmetz 2007: 323]. Na rozdíl od značné diferenciace před válkou, hodnotí Steinmetz situaci slovy: „Během 50. let a rozhodně v 60. letech (a snad i poté), metodologický pozitivismus převažoval ve vůdčích sociologických časopisech, v nejčastěji užívaných učebnicích a metodologických příručkách, na nejdůležitějších katedrách a ve vkusu významných nadaci“" [Steinmetz 2007: 339-340].

Podobně jako Steinmetz hodnotila poválečnou situaci také následující, 10. kapitola, jejímiž autory byli Craigh Calhoun a Jonathan VanAntwerpen [2007]. K charakteristice poválečné sociologie použili označení „mainstream“ sociology a poukázali na její protagonisty i na její kritiky. Koncem 60. let byli jako „mainstream“ resp. jako „sociologický establishment“ typicky označováni „tři významní představitelé“ poválečné americké sociologie: Talcott Parsons, Robert Merton a Paul Lazarsfeld [Calhoun - VanAntwerpen 2007: 372]. Kritika této, především mocenské pozice, avšak odvozeně i epistemologického přístupu, přišla s největší silou v roce 1968 na setkání Americké Sociologické Asociace. Poté se přidala i kritika $\mathrm{z}$ pozic feministické sociologie a také marxismu. Významnými kritiky byli zejména C. W. Mills a A. Gouldner. Také Calhoun s VanAntwerpenem poukazovali na spolupráci teoretika Mertona s empiricky zaměřeným metodologem Lazarsfeldem [Calhoun - VanAntwerpen 2007: 389]. Uznávali, že oni dva „jako první rozvinuli př́stup, který se později stal široce rozšířeným a normativně vyžadovaným způsobem, jak formulovat výzkumné projekty a psát články do odborných časopisü“ [Calhoun - VanAntwerpen 2007: 390]. Také Mertonovi a Lazarsfeldovi žáci se stali vůdčími osobnostmi v široké škále konkrétních výzkumných programů. Calhoun s VanAntwerpenem je vyjmenovali: „Peter Blau, James Coleman, Lewis Coser, Rose Coser, Alvin Gouldner, Seymour Martin Lipset, Alice Rossi, Peter Rossi a Philip Selznick“ [Calhoun - VanAntwerpen 2007: 390]. Podobně hodnotila působení Lazarsfeldových žáků a následovníků také Jean M. Conversová. Napsala: „Ti, kteř́i působili v BASR v padesátých letech, studenti i zaměstnanci, šírili vliv Bureau na jiné univerzity a instituce, někteří v rolích ředitelů. “ A následoval podobný seznam významných jmen: Peter Rossi, James Coleman, Robert T. Bower, Hans Zetterberg, Natalie Rogoff, Charles Glock, David Sills. A Conversová uzavřela konstatováním: „Kvantitativní a analytickou kulturu BASR šírili noví profesionálové“ [Converse 1987: 285].

Kolumbijská sociologická škola byla v české i světové produkci referována v řadě prací. Mezi nejvýznamnější z těch, které posuzovaly metodologická témata, náležely studie 
Davida Morrisona [1998], Raymonda Boudona [1993, 2010], Christiana Flecka a Nico Stehra [2010]. Ve světové produkci vyšlo několik reprezentativních sborníků statí posuzujících Lazarsfeldovo místo v poválečném vývoji sociologie, zvláště sociologické metodologie a při formování kolumbijské školy sociálního výzkumu. Jmenujme jen nejvýznamnější z nich: [Merton - Coleman - Rossi 1979; Langenbucher 1990; Lautman - Lécuyer 1998]. Př́mo Lazarsfeldovu dílu se věnovali zejména David Sills [1987], Paul Neurath [např. 1980], Raymond Boudon [1993] a Christian Fleck a Nico Stehr [2010].

Pochopitelně lze zaznamenat také kritiku tohoto stavu poválečné americké sociologie. Patrně jako první ji provedl sociolog a metodolog interpretativního zaměření Herbert Blumer [1956], Nejznámějším kritikem byl významný oponent Kolumbijské sociologické školy Charles W. Mills, autor Sociologické imaginace [Mills 2002 (orig.1959)].

Teprve v sedmdesátých a v osmdesátých letech došlo k rozsáhlejšímu narušení zjevné metodologické převahy paradigmatu, které bývá právem spojováno se jmény Paula Lazarsfelda, Samuela Stouffera, Roberta Mertona a dalších představitelů americké školy, která ukázala praktickou užitečnost sociologie v podobě výsledků empirického sociálního výzkumu. A tento empirický výzkum byl z velké části založen na metodologických principech, s nimiž přišla Kolumbijská škola Paula Lazarsfelda, Roberta Mertona a jejich žáků a spolupracovníků.

Velká většina z uvedených prací, a to jak analytických, tak i kritických, konstatovala paradigmatickou převahu metodologického pozitivismu, resp. Kolumbijské sociologické školy nebo empirického výzkumu či kvantitativní sociologie v období let 1945 až 1965. Autoři hodnotící paradigmatickou proměnu si správně všimli, že došlo ke změnám ve financování sociologie v poválečném období. Poukázali na nejednotnost teoretické sociologie, na malou podporu sociologické teorie ze strany nadací a také na jejich pragmatismus - sklon financovat výzkumy schopné přinášet prakticky využitelné výsledky. Opakovaně byla zmíněna i Lazarsfeldova schopnost formulovat výzkumné úlohy a nacházet sponzory pro jejich financování. Za významnou výhodu Kolumbijské sociologické školy byla všeobecně považována spolupráce teoretika Roberta K. Mertona, tvůrce teorií středního dosahu, s metodologem a empirickým sociologem Paulem F. Lazarsfeldem. Metody jejich spolupráce popsali Paul Neurath [1980], James Coleman [1972], sami Paul Lazarsfeld [1975] a Robert Merton [1998] a také mnozí autoři zmíněných tří sborníků prací věnovaných Paulu Lazarsfeldovi, např́íklad Seymour Martin Lipset [1979]. Lazarsfeld předal své znalosti a zkušenosti mnoha svým doktorandům a spolupracovníkům. Analýza vědeckého a pedagogického působení jeho žáků a následovníků by si zasloužila samostatnou kapitolu výzkumu k tomuto tématu.

Předkládaná studie chce být příspěvkem k poznání příčin proměn poválečné sociologie a soustředí se na podrobný rozbor konkrétních aktivit vůdčích sociologů Kolumbijské sociologické školy Paula Lazarsfelda a Roberta Mertona ve 40. a 50. letech a na posouzení výsledků jejich snažení.

\section{Zájem o vysokoškolské studium v USA po druhé světové válce}

Situaci v USA bezprostředně po 2. světové válce bylo možno charakterizovat mimo jiné příchodem velkého množství mladých mužů z bojišt 2 . světové války do civilních povolání. Řada z nich nedokončila studia na vysokých školách, protože nastoupili do armády. Jiní 
na studia za války ještě ani nestačili nastoupit. Amerika vydala zákony, které měly těmto mladým mužům a ženám - účastníkům války - zpřístupnit vysoké školy. Viz např̀. [Geiger 1993]. Podle jeho výpočtů „program, který měl bezprostřední vliv na vysokoškolské vzdělání byl GI Bill vytvořený zákonem na úpravu postavení př́slušníků armády (,Servicemen’s Adjustment Act') z 22. června 1944. Asi 15 miliónům veteránů 2. světové války byla nabídnuta příležitost pokračovat ve svém vzdělávání na náklady vlády. Přibližně dva milióny této možnosti využili a nastoupili ke studiu na vysoké škole nebo univerzitě“ [Geiger 1993: 40]. Také Turner a Turner potvrzují, že v poválečných letech projevilo zájem o vysokoškolské studium neobvykle vysoké procento mladých lidí [Turner - Turner 1990: 86-88]. Když získali první z nich bakalářské tituly, které je opravňovaly k dalšímu studiu, a to bylo na přelomu čtyřicátých a padesátých let dvacátého století, bylo nasnadě, že o nejlepší z nich budou soupeřit prestižní univerzity. Vzhledem k rostoucí užitečnosti, kterou za druhé světové války prokázaly společenské vědy, také na tomto poli bylo cítit zvýšenou aktivitu vysokých škol. I státní administrativa začala za války, a pak i po 2. světové válce, financovat společenskovědní výzkum a s vědou a výzkumem spojené příslušné fakulty renomovaných univerzit a jejich stále ambicióznější projekty. Není bez zajímavosti předeslat jeden z hlavních argumentů uváděných Kolumbijskou univerzitou a poukázat také na rostoucí poptávku mnoha pracovišst státní administrativy i aplikovaného výzkumu po profesionálně připravených výzkumnících ve společenských vědách.

Na přelomu čtyřicátých a padesátých let dvacátého století šlo tedy mnoha elitním společenskovědním pracovištím o to, aby získaly prostředky pro rozvoj svých univerzit pro výchovu nově nastupujících silných ročníků doktorandů v sociologii, politické vědě, ekonomii a dalších společenskovědních oborech. Jednou z těchto špičkových univerzit v oborech politické vědy i sociologie byla již po několik desetiletí Kolumbijská univerzita. Již od prvních desetiletí dvacátého století patřila Kolumbijská univerzita v New Yorku vedle Chicagské univerzity a Univerzity of Pennsylvania mezi pracoviště, která vychovávala nejvíce doktorandů v oborech politické vědy a sociologie.

\section{Idea Kolumbijského tréninkového centra pro doktorandy v sociálním výzkumu}

V roce 1944, tedy ještě před koncem 2. světové války, proměnila Kolumbijská univerzita svůj výzkumný ústav, původně zaměřený asi z poloviny na komunikační výzkum, na tematicky široce rozkročené společenskovědní výzkumné pracoviště začleněné do struktury univerzity a přejmenovala je na The Bureau of Applied Social Research. ${ }^{2}$ Formálně bylo volnou součástí Fakulty politických věd a sloužilo jako výzkumné pracoviště pro akademický, ale také pro aplikovaný komerční výzkum. Kromě toho bylo BASR využíváno jako školící pracoviště pro doktorandy, z velké většiny pro doktorandy katedry sociologie Kolumbijské univerzity. Paul F. Lazarsfeld, zakladatel a první ředitel výzkumného centra, významný metodolog, si lépe než ostatní sociologové v zemi uvědomoval nastalou situaci. BASR bylo již čtvrtým společenskovědním výzkumným ústavem, které Lazarsfeld založil. A ve všech případech jejich zakladatel usiloval o to, aby výzkumné aktivity jím řízených vědeckých pracovišt byly úzce propojeny s výchovou nových zkušených badatelů.

2 Podrobnosti vývoje jmenované výzkumné instituce BASR a jejích předchůdců analyzují např. Paul Neurath [1980], Ch. Fleck [2011] nebo H. Jeřábek [1997]. 
Vychovával doktorandy účastí na výzkumných projektech řešených $\mathrm{v}$ jeho centru. Jeho krédem byl workshop - výzkumná dílna. ${ }^{3}$

Ke konci čtyřicátých let vznikla z iniciativy Paula Lazarsfelda a jeho blízkého spolupracovníka Roberta Mertona nejprve neformální skupina a poté oficiální komise, která již od konce roku 1948 připravovala projekt pro vedení Kolumbijské univerzity - projekt, jehož cílem bylo zř́dit na Fakultě politických věd Institute for Training in Social Research [Memorandum 1948: 5-6]. Protože mnoho z rolí tohoto ve výhledu nového pracoviště vlastně dosud plnilo The Bureau of Applied Social Research (BASR), šlo tedy, zjednodušeně chápáno, de facto o přeměnu BASR ve školící centrum pro výchovu doktorandů $v$ metodologii a praxi empirického sociálního výzkumu.

V roce 1950 bylo vedení Fakulty politických věd Kolumbijské univerzity předloženo Memorandum z pera především R. K. Mertona a P. F. Lazarsfelda - projekt, který na 107 stránkách podrobně popisoval, jak by měla vypadat výuka v takovém centru, jak by mělo být vedeno, jaké jsou jeho cíle, jakou finanční podporu ze zdrojů univerzity a soukromých nadací očekává a o co má Kolumbijská univerzita usilovat. Výkonným ředitelem školícího pracoviště se měl stát Bernard Berelson, zkušený bývalý absolvent doktorského studia na katedře sociologie, který v té době působil na Chicagské univerzitě - blízký spolupracovník Paula Lazarsfelda a jeho př́pravného týmu. Plán byl šestiletý s prvním rokem pro př́pravu a s pěti lety experimentálního provozu takového centra [Memorandum 1948: 9]. Koncepce „institutu“ vycházela především ze zkušeností ze spolupráce metodologa a empirického výzkumníka Paula F. Lazarsfelda s renomovaným teoretikem Robertem K. Mertonem. Byli to oni dva, kdo koncepci důkladně do všech detailů promysleli, zajistili její proveditelnost a na praktických př́kladech prokázali její užitečnost a efektivitu.

Dlouho, prakticky od podzimu 1948 připravovaný projekt, procházel několika koly projednávání, nejprve na katedře sociologie a poté na úrovni Fakulty politických věd, pod níž doktorandské studium oficiálně spadalo. Jako u všech rozsáhlých projektů se počítalo s financováním ze zdrojů velkých nadací. Nejprve však bylo třeba získat podporu všech společenskovědních oborů na fakultě a také alespoň významné většiny vlivných skupin, které měly na katedře a na fakultě rozhodující slovo. Výchozí nedostatky ve výuce moderních metod sociálních věd byly definovány jasně a v Memorandu byly formulovány v pěti bodech:

a) Na žádné univerzitě nenajde student kompletní výuku všech nových technik.

b) Pokud takové metody jsou vyučovány, nejsou dobře provázány s tradičními procedurami napr. historie nebo lingvistiky.

c) Ostatní společenské vědy nemají jasno, nakolik jim mohou být tyto nové metody „sociologického" výzkumu užitečné.

d) Žádné pracoviště se systematicky nevěnuje propojování empirických procedur a teoretických analýz.

e) Neexistuje univerzitní pracoviště, které by se staralo o vývoj a testování nových metod tohoto druhu a o hodnocení jejich užitečnosti [Memorandum 1948: 5-6].

Seymour Martin Lipset, jeden z žáků, pozdějších spoluautorů a pokračovatelů Lazarsfelda a Mertona chválil, jak moc bylo možno se naučit na jejich společném semináři, který byl veden formou workshopu, výzkumné dílny slovy: „Jestliže jste se zúčastnil výzkumného semináře vedeného ke konkrétnímu projektu, byla to neuvěřitelná zkušenost“ [Lipset 1979: 12]. 
Také Výzkumná rada pro společenské vědy (Social Science Research Council) formulovala ve své zprávě potřebu „vytvoření experimentálních modelových tréninkových programů na několika univerzitách“ [Memorandum 1948: 6].

Kolumbijská univerzita mohla navázat na svou vůdčí roli, kterou prokázala v oblasti společenských věd již několikrát, at již založením School of Political Science jako jednoho z prvních center doktorského studia koncem 19. století nebo svým významným podílem na vzniku National Bureau of Economic Research po první světové válce, anebo nedávným zrrízením kolumbijského BASR. Nebylo však zřejmé, jaké by mělo být začlenění nového institutu do struktury Kolumbijské univerzity. Protože nebyly dosud definitivně vyjednány tyto administrativní okolnosti, projekt navrhoval před budoucí pětiletý projekt předsadit ještě jeden rok určený pro plánování připravovaného centra. A tento rok měl být věnován zejména př́pravě „tréninkového materiálu“ pro budoucí použití [Memorandum 1948: 7-9].

\section{Obsah projektu Kolumbijské univerzity pro trénink doktorandů}

Projekt obsahoval celou řadu detailů týkajících se struktury i obsahu studia. Jeho základní idea spočívala v představě, zřejmě vykrystalizované v četných diskusích členů přípravné skupiny, že pokročilý profesionální trénink v moderních metodách sociálního výzkumu bude průvodní doplňkovou součástí doktorského studia. Toto studium bude pro zájemce o „metodologické školení" o rok prodlouženo a trénink v metodách empirického výzkumu bude doktorand získávat postupně v průběhu tří let studia. Nakonec získá kromě diplomu ještě certifikát o absolutoriu metodologického školení [Memorandum 1948: 7-9, 53]. V Memorandu se doslova uvádí: „Předpokládáme, že tento trénink bude doplňkem, nikoli náhražkou, graduačního školení ve vlastní společenské vědě“ [Memorandum 1948: 21]. Na vysvětlení je doplněno, že dosavadní graduační vzdělávání „není dostatečné pro to, aby člověka kvalifikovalo k tomu, aby se profesionálně zabýval sociálním výzkumem“ [Memorandum 1948: 21-22].

Navrhovaná struktura studia v rámci modelu „advanced training“ kontrastovala s běžným zvykem na amerických univerzitách. Zde si studenti vybírali z nabídky kurzů podle své volby. Lazarsfeldova představa vložená do projektu počítala s dosti přesně určeným systémem několika na sebe navazujících stupňů tréninkových kurzů. I když studenti věcně směřovali každý ke svému tématu a absolvovali standardní výuku pokročilé sociologické teorie, jejich „doplňkový běh“ tréninkových kurzů směřoval od základních jednodušších k pokročilejším. Zásadně však i ve vyšších ročnících studia byl jejich studijní program metodologického tréninku sestaven předepsaným způsobem. Pokud si student např́klad ke konci studia volil nějaké metodologické kurzy, musela být tato školení spolu cíleně provázána [Memorandum 1948: 22]. Další zásadou bylo, a to opět vyplývalo z vyzkoušené praxe výuky doktorandů realizované katedrou sociologie ve spolupráci s BASR, že doktorandi byli postupně stále aktivněji zapojováni do výzkumných aktivit, nejprve do simulovaných a následně i do skutečných projektů [Memorandum 1948: 22]. Přitom však projekt doslova zdůrazňoval provázanost obsahové výuky oboru studia (např. sociologie) a metodologie výzkumu: „Profesionální student musí zvládnout jak podstatu (substance), tak metody (skills): první jej vybaví znalostmi co, a druhé mu poskytne schopnosti jak“ [Memorandum 1948: 23]. 
Podrobný popis projektu vypočítává jako využívané metody 1) případové studie konkrétních již dřive provedených výzkumů. Následuje 2) kontrolovaná účast na simulovaných a poté i na skutečných týmových výzkumných projektech. Při nich si doktorandi vyzkoušejí několik výzkumných rolí, nejlépe postupně všechny týmové úlohy [Memorandum 1948: 28-35]. Počítalo se také 3) s výzkumnou praxí, bud' ve výzkumném centru univerzity anebo s externí výzkumnou praxí v agentuře nebo vybrané instituci, s níž byl obsahově spjat studentův doktorský projekt [Memorandum 1948: 41-46]. Konečně 4) praxe v profesionálním časopise, která přinášela doktorandům zkušenosti s formulací výzkumných výsledků [Memorandum 1948: 47-49] a také 5) účast na seminární výuce mladších studentů v praktickém provádění výzkumů [Memorandum 1948: 49-51].

Obsahem projektu bylo také jeho administrativní zajištění a s ním spojené koncepční otázky. Tréninkové centrum mělo počítat s účastí čtyř typů studentů: se studenty sociologie; se studenty jiných oborů, kteří hledají tento druh tréninku; s absolventy doktorského studia z jiných univerzit, kteří hledají doplňkový profesionální trénink na Kolumbijské univerzitě; a s praktiky ze státních institucí, průmyslu, odborů apod. pro osvěžení a doplnění jejich metodologických znalostí [Memorandum 1948: 52-55]. Zbytek projektu se zabýval personálním zajištěním, charakteristikou jednotlivých pracovních pozic a konečně také finanční rozvahou. Navrhovatelé spočetli, že šestiletý projekt by vyžadoval asi 300 tisíc USD nových prostředků a 120 tisíc USD získaných využitím stávajících míst existujících pracovišt Fakulty politických věd, zejména katedry sociologie a BASR [Memorandum 1948: 99-101].

Zvláštní pozornost v projektu zasluhuje velmi věcně, podrobně a s důkladnou znalostí zpracovaná technická část projektu, $v$ níž je uveden nejen přehled tréninkového materiálu, který mají řešitelé k dispozici, ale i různé způsoby jeho využití ve výuce [Memorandum 1948: 65-90].

\section{Výhrady, pochybnosti, námitky - možné důvody, proč nebyl projekt spuštěn}

Archivní verze projektu (celkem 107 stran) zachycuje situaci v roce 1950. V této úplné podobě projekt, tedy Memorandum zpracované malou skupinou zasvěcených výzkumníků vedených Paulem Lazarsfeldem a Robertem Mertonem nikdy nebyl publikován. Lze jej studovat jen v archivu. Teprve po mnoha letech (v roce 1972) se Lazarsfeld rozhodl uveřejnit zkrácenou verzi projektu pod názvem A Profesional School for Training in Social Research $\mathrm{v}$ rámci sborníku svých známějších i méně známých textů [Lazarsfeld - Merton 1972]. Projekt sám obsahuje formulace, které vedou čtenáře k zamyšlení, nakolik mohly být přijatelné pro tradičně zaměřené sociologické teoretiky nebo pro představitele dalších společenských věd na fakultě.

V retrospektivním materiálu zveřejněném jako zpráva $\mathrm{z}$ dalšího Lazarsfeldova projektu v roce 1955 je pak uveden stručný přehled těchto možných, pravděpodobně skutečně vyjadřovaných námitek: „Myšlenka takové profesionální školy se setkala ovšem se třemi výhradami“ [PPAT 1955: 4]. První z nich byla obava, že trénink povede k výchově rutinních praktiků namísto vyváženého doktorského studia všech aspektů zkoumané látky a jejich prozkoumání. Druhou výhradou byl malý důraz kladený na teorii. Doslova byla použita formulace: „Důležitá role sociální teorie by mohla být oslabena př́lišným důrazem na metodologii.“ Navíc námitky jiných kateder poukazovaly na vzájemné překrývání metodologických orientací jednotlivých disciplín, např́iklad sociologie s ekonomií, historií nebo 
antropologií, resp. na obtíže při sladění jejich rozdílných přístupů [PPAT 1955: 4-5]. Tato zpráva, která rekapitulovala vývoj situace v letech 1950 až 1954, poskytla důležitá fakta alespoň dílčím způsobem osvětlující, proč nebyl nakonec původní šestiletý projekt spuštěn.

\section{Center for Advanced Studies v Palo Alto - konkurenční projekt Fordovy nadace}

Pravděpodobně rozhodujícím důvodem neúspěchu šestiletého projektu na založení Kolumbijského centra pro Advanced Studies in Social Research bylo rozhodnutí Fordovy nadace financovat jiný projekt směřovaný $\mathrm{k}$ podobnému cíli. Fordova nadace, jeden $\mathrm{z}$ nejaktivnějších donátorů té doby ve společenských vědách, nejprve jmenovala Bernarda Berelsona ředitelem své nově zřízené sekce pro společenskovědní výzkum [Planning Program... 1952: 3-4]. Přitom právě s ním počítalo Memorandum na místo administrativního ředitele Kolumbijského centra. V roce 1951 Fordova nadace rozhodla, že věnuje 3,5 miliónu amerických dolarů na založení zcela nového střediska v Kalifornii a zrrídila v Palo Alto Center for Advanced Studies při Stanfordově univerzitě. Formálně stejný název, ale výrazně odlišná koncepce tohoto centra znamenaly de facto konec nadějí na přijetí projektu Kolumbijské univerzity. Cílem tohoto konkurenčního centra nebylo prostřednictvím výzkumných dílen školit na společně řešených projektech budoucí výzkumníky - politology nebo sociology. V centru měli po vymezenou dobu (zpravidla po dva semestry) společně, avšak na svých vlastních individuálních projektech, pracovat jednak špičkoví osvědčení vědci a jednak nejnadějnější mladí výzkumníci - sociologové a politologové. Vedení Kolumbijské univerzity nedokázalo zabránit tomuto rozhodnutí Fordovy nadace a navíc muselo s politováním konstatovat, že patrně došlo k převzetí některých myšlenek kolumbijského projektu v souvislosti se jmenováním dr. Bernarda Berelsona ředitelem výzkumné sekce Fordovy nadace [Planning Program... 1952: 4].

\section{Přechodné období - hledání nové strategie}

Přestože Merton s Lazarsfeldem zjevně prohráli souboj o vytvoření školícího centra, nevzdali se dalších cílevědomých aktivit. Merton se stal členem Rady Fordova institutu a Lazarsfeld členem Plánovací komise institutu. Navíc, jakmile Fordovo Centrum pro pokročilá studia (Center for Advanced Studies) spustilo svůj program, tedy na podzim 1954, již do první vlny jeho frekventantů byl jako „senior researcher“ na vlastní žádost schválen Paul Lazarsfeld. ${ }^{4} \mathrm{Z}$ prostředků vítězného projektu byl tedy podpořen roční vědec-

4 Merton popisuje Lazarsfeldovo rozhodnutí strávit rok ve Fordově Advanced Center ještě po letech bez pozitivního hodnocení: „Na protest souhlasil objevit se v prvním sledu účastníkü“ [Merton 1998:188]. David Sills o Lazarsfeldovi píše: „Byl jedním ze zakladatelů Centra pro pokročilá studia ve společenských vědách ve Stanfordu v Kalifornii“ [Sills 1987:273]. Jean Conversová dle rozhovoru s Patricií L. Kendall, manželkou P. Lazarsfelda, z 24. 1. 1979 uvádí, že „Lazarsfeld strávil neštastný rok v prvním ročníku ,centra ve snaze přesvědčit ostatní účastníky pobytu, že tento individualistický přístup k vývoji společenských věd byl omylem“ [Converse 1987: 282]. Lazarsfeld bral s veškerou vážností svou úlohu člena Plánovací komise Fordova institutu. Psal podrobné analýzy a doporučení Fordově nadaci a opíral se přitom o bezprostřední pozorování a zkušenosti z prvního „běhu centra“. Všechny tři poznámky jeho nejbližších s vysokou pravděpodobností referují správně. To však nevylučuje ještě jeden, z praktického hlediska možná nejdůležitější motiv Lazarsfeldova ročního pobytu ve Fordově centru, a to možnost soustředěně a nerušeně pracovat na úlohách, které Lazarsfeld v letech 1952 až 1955 bezpochyby považoval za svi̊j hlavní úkol - dokončit a publikovat ucelený soubor metodologických studií. 
ký pobyt „nezávislého výzkumníka“ Paula Lazarsfelda, jehož projekt na přeměnu BASR na tréninkové centrum byl v soutěži poražen. Tato okolnost, jak brzy uvidíme, velmi usnadnila Lazarsfeldovi uskutečnit neméně ambiciózní projekt, který spolu s Mertonem připravili jako prŕmou odpověd na svou porážku.

Na základě materiálů Lazarsfeldova archivu ve Vídni i dle archivních materiálů Rare Book and Manuscript Library Kolumbijské univerzity v New Yorku lze dokumentovat postupný vývoj, jímž prošel Paul Lazarsfeld v letech 1950 až 1952 od myšlenek Memoranda k sepsání „náhradního“ projektu zachovávajícího racionální jádro - to nejcennější, co obsahoval původní projekt - plán na vytvoření souboru tréninkových materiálů pro školení doktorandů v empirickém sociálním výzkumu. ${ }^{5}$ Dokladem tohoto vývoje je např́klad Lazarsfeldova korespondence s významnými představiteli Kolumbijské univerzity. 21. května 1951 adresoval Lazarsfeld profesoru Schuyleru Wallaceovi čtyřstránkový dopis, $v$ němž patrně poprvé zmiňuje kompromisní návrh - vybrat z původního šestiletého projektu některé nadějné části, které by poskytly relativně rychle viditelné výsledky a připravit „náhradni“', jen dvouletý, projekt s menšími finančními, organizačními i lidskými náklady. Součástí dopisu je věta, která dává tušit, jakým směrem Lazarsfeld uvažoval: „Vždycky jsme zdůrazňovali, že zajištění výukových materiálů bude jeden z hlavních cílů projektu“ [dopis PFL to Schuyler Wallace z 21. 5. 1951: 1]. Dále je ještě konkrétnější, když piše o tom, že tak vzniknou „cenné tréninkové materiály pro jiné univerzity, které by si přály učit sociální výzkum, aniž by byla založena plně rozvinutá škola nebo ústav" [ibid.: 2]. Lazarsfeld počítá s dvouletým grantem, $\mathrm{k}$ jehož zajišsění by rád použil 60 tisíc USD, které Fordova nadace věnovala Kolumbijské univerzitě na př́pravu „tréninkového centra“ a plánuje požádat Rockefellerovu nadaci o druhých 60 tisíc USD: „Na dvouletém základě by pak program vyžadoval rozpočet $\$ 120$ 000. Pokud Kolumbijská komise pro Fordův grant poskytne polovinu z této částky, lze důvodně očekávat, že Rockefellerova nadace by mohla přispět druhou polovinou" [ibid.: 3].

\section{The Planning Project for Advanced Training (PPAT)}

Dne 29. února 1952 Lazarsfeld píše oficiální dopis děkanovi Fakulty politických věd profesoru Johnu A. Kroutovi, v němž žádá o schválení menšího projektu jen na úrovni katedry sociologie a informuje jej o struktuře, hlavním zaměření projektu a jeho návaznosti na původní plán. Poprvé je zde použito označení Planning Project on Advanced Training in Social Research (PPAT). Počítá se spuštěním půlroční prípravné fáze projektu od 1. 3. 1952 do 1. 10. 1952 a s dvouletým trváním samotného projektu od 1. 10. 1952 do 1. 10. 1954. Uvádí zde již informaci o jmenování Dr. Bernarda Berelsona do vysoké pozice u Fordovy nadace. Žádá děkana, aby jej jmenoval ředitelem projektu PPAT a doporučuje mu jmenovat komisi pro tento projekt ve složení dalších čtyř profesorů: Otto Klineberg, Robert Lynd, Robert Merton a Schuyler Wallace [Dopis P. Lazarsfelda děkanovi Johnu A Kroutoviz 29. 2. 1952].

Tento projekt byl rozsahem i finančními nároky rozhodně menší než původní šestiletý plán. Byl méně závislý na vnějších vlivech, byl tedy realističtější. Rozhodně však nebyl

\footnotetext{
Přitom empirický sociální výzkum chápali Lazarsfeld, Merton i celá kolumbijská škola jako soubor výzkumných činností podmíněný teorií, vycházející z ní a k jejímu obohacení opět směřující [Fleck - Stehr 2010].
} 
méně ambiciózní. Nebyl orientován na institucionální ani administrativní změny, i když si formálně kladl za úkol tyto otázky vyjasnit. Jeho obsahem nebylo ani založení tréninkového centra ani institucionální proměna výzkumného ústavu na tréninkové centrum. Název projektu The Planning Project... sice napovídal, že připravuje budoucí změny. Nekladl si je však za cíl. Obsahově se jednalo téměř výhradně o projekt zaměřený na prostředky a formy výuky budoucích doktorandi̊. Projekt PPAT byl spuštěn bez velké publicity dne 1. 3. 1952. Měl ukázat, jak má vypadat př́íprava doktorandů na budoucí práci sociologa výzkumníka. A klíčem k praktické podobě takového projektu byla postupná př́íprava rozsáhlého souboru tréninkových materiálů - vlastně pokročilých učebnic a souborů nejkvalitnějších textů ukazujících, jak se dělá špičkový společenskovědní výzkum - jakási „metodologie krok za krokem“. Znalci historie sociologické práce si vzpomenou na slavnou "green bible“ Roberta E. Parka a Ernesta W. Burgesse - na jejich Introduction to the Science of Sociology [Park - Burgess 1921]. Také toto kompendium ukazovalo na př́kladech minulých výzkumů chicagským doktorandům (v roce 1921) jak se dělá věda sociologie.

V materiálu nazvaném Planning Program for Advanced Training in Social Research z 11. 11. 1952, patrně stručné zprávě z úvodního pololetí řešení projektu, je, jistě ne náhodou, poprvé zmíněn Lazarsfeldův záměr vydat Selected Readings in Social Research Methods, což byl evidentně pracovní název pro později slavné dílo The Language of Social Research [Planning Program... 1952: 10].

Aktivita Lazarsfelda s Mertonem vedla ke zř́ízení komise, a ta již v polovině roku 1952 představila projekt plánovaný na dva a půl roku s velmi detailním přehledem o jeho obsahu a velmi jasnou představou o jeho financování z mimouniverzitních soukromých nadačních zdrojů. Kolumbijská univerzita získala na tento PPAT projekt 60 tisíc USD od Rockefellerovy nadace a komise měla i příslib, že může využít dalších 60 tisíc USD zaslaných Kolumbijské univerzitě již dříve Fordovou nadací. Celkem bylo tedy na projekt PPAT získáno 120 tisíc amerických dolarů. Ve srovnání s 3,5 milióny dolarů, které věnovala Fordova nadace na zř́zení Center for Advanced Studies v Palo Alto se jednalo o třicetkrát menší částku. Nezapomeňme však, že nebylo třeba stavět budovy, zařizovat a vybavovat učebny, najímat a platit správní personál, hledat a platit celý aparát nákladného projektu. Teprve podrobný pohled na obsah projektu PPAT, na jeho jednotlivé položky a naplánované úkoly přehledně ukáže, v čem spočívalo kouzlo projektu. Tento projekt byl detailně promyšlenou investicí relativně velmi vysoké finanční částky do sociologické metodologie jednoho výzkumného zaměření - kolumbijského metodologického výzkumného paradigmatu. Přehled úkolů, které si projekt PPAT předsevzal, totiž téměř přesně kopíroval seznam problémů, které Lazarsfeld již deset let spolu se svými spolupracovníky řešil a v nichž plánoval v dalších letech pokračovat. Vlastně to byly plány na jeho další publikace, často připravované koordinovaně s dalšími metodologickými partnery a ve spoluautorství s mladšími kolegy. Jak ukázal další vývoj, jednalo se s největší pravděpodobností o vysoce efektivní investici. Zajistila totiž významný vliv Lazarsfeldovy metodologické školy po další dvě desetiletí.

\section{Jaký byl obsah projektu PPAT?}

Pro mnoho dnešních čtenářů bude pravděpodobně překvapivé, že jen úzce tematicky vymezený soubor metodologických prací Lazarsfelda a jeho nejbližších spolupracovníků 
byl financován tak vysokou částkou přes sto tisíc amerických dolarů (roku 1952). Poslechněme si Lazarsfeldovy autentické argumenty citované ze zprávy projektu PPAT. Retrospektivně citované úkoly projektu jsou doslovně uvedeny ve zprávě z PPAT projektu zpracované a zaslané vedení univerzity a oběma nadacím na podzim roku 1955, tedy již po ukončení projektu.

Zpráva nejprve uvádí cíle projektu, kterými jsou: „Připravit konkrétní dokumentaci a školící materiál, který poskytne mnohem barvitějš́ obraz toho, jak vypadá pokročilý trénink (advanced training) ve společenskovědním výzkumu" [PPAT 1955: 5]. A o několik stránek dále, v oddíle nazvaném Areas of Concentration (Oblasti, na které jsme se soustředili), je napsáno: „Během prvních dvou let projektu byla většina úsilí i času realizačního týmu věnována [...] př́pravě dokumentačního materiálu“ [PPAT 1955: 11]. Nebylo však financováno zdaleka všechno, co by mohla sociologická metodologie řešit: „Za prvé jsme z projektu vyloučili ty výzkumné techniky, pro něž již existovala kvalitní literatura. Sem náleží výběrové techniky, experimentální metody a techniky konstrukce dotazníků. [...] Dále jsme nevěnovali zvláštní pozornost těm oblastem, [...], kde dosud nebylo dosaženo podstatného pokroku v jejich kodifikaci“ [PPAT 1955: 11-12].

Hlavní body projektu obsahují „pět hlavních oblastí soustředěného zájmu:

A) Tvoření pojmů a jejich indikátorů:

B) Současně probíhající (simultánní) analýza souboru proměnných (survey analysis): [...].

C) Empirické studium krátkodobých změn (panelová technika): [...].

D) Formalizace kvalitativních procedur: Postupovali jsme tak, že jsme se zabývali specifickými kvalitativními texty a ,převáděli jsme je do jazyka empirického sociálního výzkumu.

E) Vztah empirického sociálního výzkumu k problémům historiografie a politické teorie: [...] to zahrnuje užitečnost moderního sociálního výzkumu jiným oborům, jako jsou ekonomie nebo antropologie" [PPAT 1955: 12-15].

Pokud by někdo náhodou dobře nerozuměl, co znamená výraz „moderní sociální výzkum“, tato zpráva to uvádí výslovně: „Tyto první tři oblasti - tvorba proměnných, obecná analýza vztahů mezi nimi a jejich vzájemné interakce v čase - př̌edstavují jádro moderního sociálního výzkumu" (zdůraznil HJ) [PPAT 1955: 14]. A pro lepší porozumění všem těm, kteř́ by snad chtěli některé jiné oblasti v rámci působnosti Fakulty politických věd považovat za dostatečně důležité, aby byly také financovány, je ve zprávě jasně uvedeno, že „jisté specifické aspekty [...] jsou právě zkoumány někde jinde“ [PPAT 1955: 15]. A Michiganská univerzita a Cornellova univerzita jsou uvedeny jako př́klad a vše je doplněno jasným vyjádřením, které mělo být srozumitelné komukoliv: „Je zjevné, že by pro náš projekt bylo nemožné pokrýt všechny tyto rozvíjené oblasti mezioborové aktivity" [PPAT 1955: 15].

\section{Publikace financované projektem PPAT}

V jedné ze závěrečných částí Zprávy z projektu PPAT nazvané Současný stav materiálu - publikace a dokončené rukopisy je uveden překvapivě rozsáhlý přehled knih publikovaných během pouhých dvou let projektu k úzce vymezenému souboru témat. Byla to řada metodologicky orientovaných, projektem inspirovaných, podpořených a financovaných monografí a článků. Mezi těmito publikacemi najdeme: 
1. The Language of Social Research, rozsáhlou reprezentativní publikaci, kterou editovali Paul Lazarsfeld a Morris Rosenberg [PPAT 1955: 15-16] [Lazarsfeld-Rosenberg (ed.) 1955];

2. učebnici Herberta Hymana Survey Design and Analysis [PPAT 1955: 16] [Hyman 1955];

3. kolektivní monografii věnovanou panelové analýze, kterou sestavil professor Lee Wiggins [PPAT 1955: 17];

4. sborník statí Mathematical Thinking in the Social Sciences, který založil nový směr metodologie - matematickou sociologii, editovaný Paulem Lazarsfeldem [PPAT 1955: 18] [Lazarsfeld (ed.) 1955];

5. A Formalization of Functionalism, svazek, který editoval Ernest Nagel, v němž Nagel vysvětluje Mertonovo pojetí funkcionální analýzy [PPAT 1955: 18];

6. dvě rozsáhlé stati v knížce, kterou editovala Mirra Komarovsky Common Frontiers of the Social Sciences spolu s vysvětlením, že projekt „přispěl na editační práce potřebné k vydání celé knížky proto, aby jasně ukázal povahu mezioborové spolupráce a poskytl našim dvěma studiím adekvátní rámec" [PPAT 1955: 20] [Komarovsky 1956].

A některé další drobnější publikace, jako Friendship as a social process [Lazarsfeld Merton 1954] - společný článek teoretika Mertona a metodologa Lazarsfelda, dlouhá studie Alana Bartona a P. F. Lazarsfelda Some Functions of Qualitative Analysis in Social Research [Lazarsfeld - Barton 1982 (orig. 1955)] a také několik dalších článků a „tréninkových materiáli̊“ " $P P A T$ 1955: 18].

Čtyři z těchto knih - 1) 2) 4) a 5) - byly vydány v prestižním nakladatelství The Free Press. Lazarsfeld o tom doslova uvádí: „Ediční řada publikací, pro niž jsme uzavřeli smlouvu s nakladatelstvím Free Press" [PPAT 1955: 17]. To bylo mimořádně důležité pro budoucí vnímání Lazarsfeldovy metodologie a pro další úspěch Kolumbijské školy sociálního výzkumu.

Zvláště rozsáhlý svazek později slavného díla The Language of Social Research, které sloužilo po mnoho let jako vůdčí učebnice pro doktorské studijní programy na mnoha univerzitách v Evropě a ve světě, by pravděpodobně nebyl publikován s takovou propagací, podporou a v tak prestižním provedení, kdyby byl vydán bez finanční podpory tohoto PPAT projektu a kdyby nebyl vydán ve Free Press. Navíc z prostředků projektu bylo pro tuto knihu financováno sedm originálních metodologických textů. Vydáním ve Free Press byla stejně zvýrazněna důležitost Hymanovy knihy Survey Design and Analysis, která sloužila několik let jako nejvhodnější učebnice analytického výzkumného designu zvláště na některých významných univerzitách ve Spojených státech. A v neposlední řadě je třeba zdůraznit, jaký význam mělo vydání souboru článků Mathematical Thinking in the Social Sciences v prestižním vydavatelství The Free Press. Tento svazek by jistě nezaznamenal tak výraznou citovanost a nebyl by později označován za počátek matematické sociologie, kdyby vyšel jen jako běžný sborník z jedné z nesčetných konferencí.

\section{Shrnutí a závěry}

Ptáme se: Jak se prosadila Kolumbijská sociologická škola v poválečné sociologii? A pokoušíme se odpovědět výčtem promyšlených aktivit Paula Lazarsfelda a Roberta Mertona $\mathrm{v}$ padesátých letech a zejména pak poukazem na publikační výsledky projektu PPAT, 
jímž se „kolumbijská škola sociálního výzkumu“ prosadila ve světovém měřítku tehdejší sociologické produkce.

Na počátku byla cílevědomá snaha Paula Lazarsfelda o uskutečnění jeho celoživotního snu. Chtěl připojit ke svému nejslavnějšímu výzkumnému ústavu BASR tréninkové centrum pro výchovu budoucích výzkumníků. $\mathrm{V}$ tomto jeho úsilí jej obětavě podporoval jeho kolega a dlouholetý spolupracovník Robert K. Merton. Prostředkem školení doktorandů měl být především workshop - sociologická výzkumná dílna. Dva roky intenzívní práce, jejímž svědectvím jsou analýzy a př́pravné texty a rozsáhlé Memorandum, jehož autory byli Merton s Lazarsfeldem, ani stručnější verze projektu projednávaná na úrovni fakulty v roce 1951, to vše nevedlo $k$ vítěznému cíli. Projekt tréninkového centra pro budoucí výzkumníky se nezdařil. Fordova nadace financovala konkurenční projekt. Založila zcela nové Center for Advanced Studies v Kalifornii v Palo Alto při Stanfordově univerzitě.

$\mathrm{V}$ tom okamžiku Lazarsfeld nesložil zbraně a přeorientoval své úsilí na prezentaci hmatatelných výsledků práce své metodologické dílny. Namísto 3,5 miliónu, které Fordova nadace investovala do založení nového centra, požádali Lazarsfeld s Mertonem o 120 tisíc dolarů. Třicetkrát nižší finanční prostředky se Lazarsfeld rozhodl využít intenzívněji, více zacíleně. A zdá se, že tentokrát trefil do černého. Podařilo se mu v průběhu roku 1952 prosadit PPAT projekt, na jehož podporu Rockefellerova nadace vynaložila 60 tisíc USD a z prostředků Fordovy nadace byla využita stejně vysoká částka. Lazarsfeld a jeho spolupracovníci použili tyto prostředky $\mathrm{k}$ podpoře vzniku a vydání několika klíčových metodologických monografií, učebnic a sborníků. Důležité bylo, že s podporou projektu PPAT všechny klíčové publikace vydalo elitní nakladatelství The Free Press, s nímž navíc Lazarsfeld uzavřel smlouvu o založení ediční řady sociologických metodologických publikací. Nad jejich vydáváním si po celých nejméně deset let podržel kontrolu. ${ }^{6}$ Aby se mohl na tuto metodologickou práci plně soustředit, osvobodil se Lazarsfeld na celý rok 1954/55 od úředních povinností na Kolumbijské univerzitě. De facto si tak prodloužil PPAT grant, který počátkem ř́ína 1954 právě končil, o další rok, kdy se mohl sociologické metodologii plně věnovat. Tento mimořádný, původně neplánovaný, „sabbatical year“ strávil v nově založeném Center for Advanced Studies Fordovy nadace v Kalifornii [Merton 1998: 188]. Lze předpokládat, že ty metodologické publikace, jejichž editaci nestačil dokončit a připravit je do tisku během relativně krátkých dvou let projektu PPAT, Lazarsfeld dokončoval právě zde, v Palo Alto. Svědčí o tom data vydání některých výsledků projektu až v roce 1955.

Odhadem 90 \% finanční subvence věnované Fordovou a Rockefellerovou nadací na projekt PPAT bylo použito na tvorbu a vydání klíčových metodologických publikací k problémům, které sám Lazarsfeld definoval v cílech projektu PPAT jako prioritní úkoly moderního sociálního výzkumu. Až na výjimky několika doplňkových publikací bylo asi 110 tisíc dolarů věnováno na akademickou sociologickou metodologii jednoho paradigmatického zaměření. Jak vysvětlit velmi jednostranné tematické zaměření projektu PPAT i stejně vyhraněné čerpání peněz z jeho prostředkủ? Jen Lazarsfeld a jeho pracovní skupina byli připraveni k přesnému stanovení úkolů projektu PPAT. A jen Lazarsfeld, s podporou R. K. Mertona a úzkého okruhu svých nejbližších spolupracovníků, byl schopen nabídnout a rychle připravit do tisku kvalitní publikace, které ve svém souhrnu dodnes představují jádro „kolumbijské metodologické školy“. Při tomto svém skvělém „kousku“ měl Lazarsfeld

6 Ještě v šedesátých letech vycházejí v této metodologické řadě Free Press práce kolumbijské školy. 
zjevně plnou podporu svého druha Roberta Mertona. A tak se jim nakonec podařilo Lazarsfeldovu snad největši životní prohru, ztrátu jeho životního snu - školicího střediska proměnit $\mathrm{v}$ neméně hodnotný zisk na důležitém hřišti, kde se hrálo ne o desítky nebo stovky doktorandů, ale o dvě generace studentů sociologie. Publikované výsledky Projektu PPAT měly významný dopad. ${ }^{7}$ Byly použivány na mnoha významných univerzitách v USA, ale navíc také na desítkách dalších pracovišt ve Velké Británii, ve Francii, kde Lazarsfeld publikoval, několikrát celý rok přednášel a kde našel významné spolupracovníky, ${ }^{8} \mathrm{v}$ poválečném Německu, kde podle vzoru jeho BASR manželé Peter a Elisabeth Noelle-Neumann založili hned po válce Institut für Demoskopie v Allensbachu, ${ }^{9} \mathrm{v}$ Rakousku nebo v Norsku, kde ve Vídni i v Oslo Lazarsfeld osobně podpořil založení výzkumných institutủ, ${ }^{10}$ v Itálii, kde má kolumbijská škola dodnes své pokračovatele, ${ }^{11}$ ve Švédsku, ${ }^{12}$ v Jugoslávii a ve státech stř̌ední Evropy, zejména v Polsku, Československu a Madarsku, kde Lazarsfeld přednášel jako lektor UNESCO v kurzech pokročilé metodologie, ale také na dalších špičkových pracovištích ve světě. Všichni tito účastníci Lazarsfeldových kurzů, spoluautoři jeho knih a článků, jeho doktorandi a mnozí z nich také jako učitelé využívající vydané metodologické publikace, ředitelé výzkumných pracovišt a kateder zř́zených ve stejném duchu jako BASR, vykonali v souhrnu více práce, než měl v původním plánu Lazarsfeldova a Mertonova Memoranda za úkol jediný Institut for Advanced Training in Social Research.

Prostř̌ednictvím učebnic, monografií i článkủ, ale také díky desítkám a stovkám Lazarsfeldových a Mertonových žáků a následovníků, kteří přejali kolumbijský model empirického výzkumu a jeho metodologie od svých učitelů a používali tyto učebnice ve výuce, se podařilo kodifikovat model kolumbijské školy sociálního výzkumu jako převažující paradigma poválečného sociologického výzkumu. ${ }^{13}$

Toto poválečné vítězství „,kolumbijské školy sociálního výzkumu“ je dostatečně patrné až s časovým odstupem desítek let a je možné je posoudit právě v kontrastu se současnou

7 Za úspěchy navázané na Projekt PPAT lze považovat nejen vydání výše uvedených publikací. V USA Lazarsfeldův blízký spolupracovník Morris Rosenberg vydal v šedesátých letech metodologickou monografii k Survey Analysis [Rosenberg 1968]. Free Press publikovalo pokračování slavného The Language of Social Research [Lazarsfeld - Passanella - Rosenberg 1972].

8 Raymond Boudon a Francois Chazel s Lazarsfeldem společně editovali tři díly metodologických sborníků v letech 1965, 1966 a 1970 [Lazarsfeld - Boudon - Chazel 1965, 1966, 1970]. Oni i jejich francouzští spoluautoři spolu s Lazarfeldovými žáky z jeho přednášek na Sorbonně šírili ve Francii myšlenkový model Paula Lazarsfelda a jeho „kolumbijské metodologické školy“, viz např. [Boudon 1993, 2010].

9 Elisabeth Noelle-Neumann byla jednou z nejvýznamnějších evropských šiřitelek odkazu P. Lazarsfelda. O způsobu práce jejího centra svědčí její učebnice metod výzkumu [Noelle 1967; Noelle-Neumann - Petersen 2000], o návaznosti na práci Paula F. Lazarsfelda např. její PS-škála pro měření názorového vůdcovství.

10 Institute for Social Research at the University in Oslo, Institute for Advanced Studies in Vienna.

11 Vittorio Capecchi byl spoluautorem a spolueditorem italské obdoby LSR [Lazarsfeld - Capecchi 1967]. Alberto Marradi, Fabrizio Martiro, Carmelo Lombardo i další metodologové pokračují v Itálii v linii lazarsfeldovské metodologie [např. Campelli - Fasanella - Lombardo 1999].

12 Hans Zetterberg, metodolog, zakladatel nejvýznamnějšího švédského výzkumného ústavu pro výzkum veřejného mínění, je autorem čtyřdílné metodologické publikace [Zetterberg 2013] a byl až do své nedávné smrti významným pokračovatelem Lazarsfelda a Mertona.

13 Nakolik všichni ti, kteří přejímali „Kolumbijský model sociologického výzkumu“, skutečně pokračovali ve stejném duchu jako Lazarsfeld s Mertonem, bude třeba podrobit dalšímu zkoumání. Použití survey jako hlavní metody a důraz kladený na empirická data, jejich smysluplnou interpretaci a praktické využití, ještě nemuselo znamenat „replikaci kolumbijského modelu sociologie“. Převaha „kvantitativní orientace“ a „metodologického pozitivismu“ v padesátých a šedesátých letech dvacátého století se prosadila. Způsob sociologické práce a především kvalitní výchova výzkumníků vlastní „Kolumbijské sociologické škole“ se uplatnily především tam, kde model s plným pochopením prosazovali žáci a následovníci Paula Lazarsfelda a Roberta Mertona. 
situací. Možná si ani sám Lazarsfeld neuvědomoval dosah projektu PPAT, který byl zřejmě mnoha jeho univerzitními kolegy považován jen za „skromnou náhradu“ „velkého projektu tréninkového centra“. Přitom je však vysoce pravděpodobné, že dosud nikdy v historii nebylo tak velké množství finančních prostředků využito s tak výraznou efektivitou k prosazení myšlenek sociologické metodologie. Díky významným publikacím a jejich následnému dopadu lze dobře promyšlenou a cílevědomou investici 120 tisíc USD projektu PPAT považovat za mimořádný úspěch Kolumbijské sociologické školy.

\section{Literatura}

Balon, Jan [2011]. Sociologie v USA. Historické kontextualizace. Praha: SLON.

Blumer, Herbert [1956]. Sociological Analysis and the Variable. American Sociological Review 21 (6): 683-690.

Boudon, Raymond [1993]. Introduction. In. Lazarsfeld, Paul. On Social Research and Its Language. Ed. R. Boudon. Chicago: University of Chicago, s. 1-29.

Boudon, Raymond [2010]. Lazarsfeld's main intellectual intuitions. Preface to Paul F. Lazarsfeld. An Empirical Theory of Social Action: Collected Writings. Ed. Ch. Fleck - N. Stehr. Oxford: The Bardwell Press, s. i-x.

Calhoun, Craig (ed.) [2007]. Sociology in America. A History. Chicago - London: Chicago University Press.

Calhoun, Craig - VanAntwerpen, Jonathan [2007]. Orthodoxy, Heterodoxy, and Hierarchy: „Mainstreem“ Sociology and Its Challengers. In. Calhoun, Craig (ed.). Sociology in America. A History. Chicago London: Chicago University Press, s. 367-410.

Campelli, E. - Fasanella, A. - Lombardo, C. (ed.) [1999]. Paul Lazarsfeld: Un „Classico“ Marginale. Sociologia e ricerca sociale XX (zvláštní dvojčíslo 58-59).

Coleman, James S. [1972]. Paul Lazarsfeld's Work in Survey Research and Mathematical Sociology. In. Lazarsfeld, Paul F. Qualitative Analysis. Historical and Critical Essays. Boston: Allyn and Bacon, s. 395-409.

Converse, Jean M. [1987]. Survey Research in the United States: Roots and Emergence 1890-1960. Berkeley: University of California Press.

Fleck, Christian [2011]. A Transatlantic History of the Social Sciences. Robber Barons, the Third Reich and the Invention of Empirical Social Research. London: Bloomsbury Academic.

Fleck, Christian - Stehr, Nico [2010]. Introduction. From Vienna to New York. In. Lazarsfeld, Paul F. An Empirical Theory of Social Action: Collected Writings. Ed. Ch. Fleck - N. Stehr. Oxford: The Bardwell Press, s. 1-46.

Geiger, Roger L. [1993]. Research and Relevant Knowledge. American Research Universities Since World War II. New York: Oxford University Press.

Hyman, Herbert [1955]. Survey Design and Analysis. New York: Free Press.

Jeřábek, Hynek [1997]. Paul Lazarsfeld a počátky komunikačního výzkumu. Praha: Karolinum.

Komarovsky, Mirra (ed.) [1956]. Common Frontiers of the Social Sciences: The Interrelations of History, Economics, and Sociology. Glencoe, Ill.: Free Press.

Langenbucher, Wolfgang, R. (ed.) [1990]. Paul F. Lazarsfeld (Die Wiener Theorie der empirischen Sozialund Kommunikationsforschung). Wien: Ölschläger Vrlg.

Lautman, Jacques - Lécuyer, Bernard-Pierre (ed.) [1998]. Paul Lazarsfeld (1901-1976). La socioloie de Vienne à New York. Paris: L'Harmattan.

Lazarsfeld, Paul F. - Merton, Robert K. [1954]. Friendship as Social Process: A Substantive and Methodological Analysis. In. Berger, Morroe - Abel, Theodore - Page, Charles H. (ed.). Freedom and Control in Modern Society. New York: D. van Nostrand, s. 18-66.

Lazarsfeld, Paul F. - Barton, Allen H. [1982, orig. 1955]. Some Functions of Qualitative Analysis in Social Research. In. Kendal, Patricia L. (1982). The Varied Sociology of Paul F. Lazarsfeld. Writings. Ed. P. L. Kendal. New York: Columbia University Press, s. 239-285, 377-381.

Lazarsfeld, Paul F. - Rosenberg, Morris (ed.) [1955]. The Language of Social Research. New York: Free Press. 
Lazarsfeld, Paul F. (ed.) [1955]. Mathematical Thinking in the Social Sciences. New York: Free Press.

Lazarsfeld, Paul F. - Boudon, Raymond (ed.) [1965]. La vocabulaire des sciences sociales. Méthodes de la sociologie. Vol. I. Paris: Mouton.

Lazarsfeld, Paul F. - Boudon, Raymond (ed.) [1966]. L'analyse empirique de la causalité. Méthodes de la sociologie. Vol. II. Paris: Mouton.

Lazarsfeld, Paul F. - Capecchi, Vittorio [1967]. Metodologia e ricerca sociologica. Saggi sociologici. Bologna: Editr. il Mulino.

Lazarsfeld, Paul F. - Boudon, Raymond - Chazel, Francoise (ed.) [1970]. L'analyse des processus sociaux. Méthodes de la sociologie. Vol. III. Paris: Mouton.

Lazarsfeld, Paul F. - Passanella, Ann K. - Rosenberg, Morris (ed.) [1972]. Continuities in the Language of Social Research. New York: Free Press.

Lazarsfeld, Paul F. - Merton, Robert K. [1972]. A Profesional School for Training in Social Research. In. Lazarsfeld, Paul F. Qualitative Analysis. Historical and Critical Essays. Boston: Allyn and Bacon, s. 361-391.

Lazarsfeld, Paul F. [1975]. Working with Merton. In. Coser, Lewis A. (ed.) The Idea of Social Structure. Papers in Honor of Robert K. Merton. New York: Hartcourt, Brace, Johanovich, s. 35-66.

Lipset, S. M. [1979]. Some personal notes for a history of the department of Sociology at Columbia. In. Merton, R. K. - Coleman, J. S. - Rossi, P. H. (ed.). Qualitative and Quantitative Social Research. Papers in Honor of Paul F. Lazarsfeld. New York: Free Press.

Merton, Robert K. [1998]. Working with Lazarsfeld. Notes and contents. In. Lautman, Jacques - Lécuyer, Bernard-Pierre (ed.). Paul Lazarsfeld (1901-1976). La socioloie de Vienne à New York. Paris: L'Harmattan, s. 163-211.

Merton, Robert K. - Coleman, James S. - Rossi, Peter H. (ed.) [1979]. Qualitative and Quantitative Social Research. Papers in Honor of Paul F. Lazarsfeld. New York: Free Press.

Mills, Charles W. [2002] (orig.1959). Sociologická imaginace. Praha: SLON.

Morrison, David E. [1998]. The Search for a Method. Focus Groups and the Development of Mass Communication Research. Luton: University of Luton Press.

Neurath, Paul [1980]. Paul Lazarsfeld 1901-1976 und die Entwicklung der empirischen Sozialforschung. Wien: Institut für Soziologie, Universität Wien.

Noelle, Elisabeth [1967]. Úvod do metod demoskopie. Praha: Svoboda.

Noelle-Neumann, Elisabeth - Petersen, Thomas [2000]. Alle, nicht jeder. Einführung in die Methoden der Demoskopie. Berlin: Springer. (3. vyd., přepracované a doplněné)

Park, Robert E. - Burgess, Ernest W. [1921]. The Introduction to the Science of Sociology. Chicago: The University of Chicago Press.

Petrusek, Miloslav [1993]. Teorie a metoda v moderní sociologii. Praha: Karolinum.

Petrusek, Miloslav [2000]. Poslední klasik moderní sociologie - Robert King Merton. In. Merton, R. K. Studie ze sociologické teorie. Praha: SLON, s. 230-263.

Platt, Jennifer [1996]. A History of Sociological Research Methods in America 1920-1960. Cambridge: Cambridge University Press.

Rosenberg, Morris [1968]. The Logic of Survey Analysis. New York: Basic Books.

Sills, David L. [1987]. Paul F. Lazarsfeld 1901-1976. A Biographical Memoir. In. Biographical Memoirs, vol. 56. Washington, D.C.: The National Academy Press, s. 251-282.

Skovajsa Marek - Balon, Jan [2017]. Sociology in the Czech Republic. Between East and West. London: Palgrave.

Steinmetz, George [2007]. American Sociology before and after World War II: The (Temporary) Settling of a Disciplinary Field. In. Calhoun, Craig (ed.). Sociology in America. A History. Chicago - London: Chicago University Press, s. 314-366

Turner, Stephen P. - Turner, Jonathan H. [1990]. The Impossible Science. An Institutional Analysis of American Sociology. Newbury Park, CA: SAGE.

Zetterberg, Hans L. [2013]. The Many-Splendored Society. Vol. 1-4. Sweden, Bromma: Zetterberg. 


\section{Archivní prameny}

Memorandum [1948]. „Proposal to establish an Institute for Training in Social Research. A Memorandum submitted by the Department of Sociology Columbia University. "Archiv Paula Lazarsfelda, Wien, Box B-0420, [Teil 5], $107 \mathrm{~s}$.

PPAT [1955]. „Planning Project for Advanced Training in Social Research. PPAT Fall 1955“. N.Y.: Columbia University. Archiv Paula Lazarsfelda, Wien, Box B-0420, [Teil 3]; 30+3 s.

Planning Program ... [1952]. „Planning Program for Advanced Training in Social Research.“ November 1952. Archiv Paula Lazarsfelda, Wien, Box B-0420, [Teil 1]; 15 s.

Dopis Paula Lazarsfelda Schuyleru Wallacovi 21. 5. 1951. Archiv Paula Lazarsfelda, Wien, Box B-0590; Training Center PPAT [Teil 3]; 4 s.

Dopis Paula Lazarsfelda děkanovi Johnu A. Kroutovi z 29. 2. 1952. Archiv Paula Lazarsfelda, Wien, Box B-0590; Training Center PPAT [Teil 4]; 6 s.

Hynek Jeřábek $\left({ }^{\star} 1949\right)$ vyučuje metody a dějiny empirického výzkumu a sociologii komunikace na Fakultě sociálních věd Univerzity Karlovy v Praze a na Filozofické fakultě Západočeské univerzity v Plzni. Dlouhodobě se věnuje historii sociologického výzkumu a dílu Paula Lazarsfelda. Publikoval články již v minulých ročnících Historické sociologie a je autorem několika knižních publikací: Paul Lazarsfeld a počátky komunikačního výzkumu (1997), anglicky (Routledge 2017); Paul Lazarsfeld's Research Methodology (2006); Slavné sociologické výzkumy (1899-1949) (SLON 2014); Úspěšné ženy ve stínu slavných mužů ( $v$ tisku Karolinum 2019) aj. 